\title{
Synergistic Antimicrobial Effect of Lactiplantibacillus plantarum and Lawsonia inermis Against Staphylococcus
} \section{aureus}

\author{
Dalia Elebeedy', Aml Ghanem ${ }^{2,3}$, Marwa El-Sayed $^{4}$, Eman Fayad ${ }^{5}$, Ola A Abu Ali ${ }^{6}$, Amal Alyamani $^{5}$, \\ Asmaa Sayed Abdelgeliel $\mathbb{D}^{7}$
}

'College of Biotechnology, Misr University for Science and Technology (MUST), 6th of October City, 12573, Egypt; ${ }^{2}$ Molecular Biology Department, Genetic Engineering and Biotechnology Research Institute, University of Sadat City, Sadat City, 12573, Egypt; ${ }^{3}$ School of Biotechnology, Badr University in Cairo, Badr City, Cairo, I 1829, Egypt; ${ }^{4}$ Department of Microbiology and Immunology, Faculty of Medicine, South Valley University, Qena, 83523, Egypt; ${ }^{5}$ Department of Biotechnology, Faculty of Science, Taif University, Taif, 21944, Saudi Arabia; ${ }^{6}$ Department of Chemistry, College of Science, Taif University, Taif, 21944, Saudi Arabia; ${ }^{7}$ Department of Botany \& Microbiology, Faculty of Sciences, South Valley University, Qena, 83523, Egypt

Correspondence: Marwa El-Sayed, Department of Microbiology and Immunology, Faculty of Medicine, South Valley University, Qena, 83523, Egypt, Tel +20 1003717916, Fax +20 963216128, Email marwa.elsayed@med.svu.edu.eg; Asmaa Sayed Abdelgeliel, Department of Botany \& Microbiology, Faculty of Sciences, South Valley University, Qena, 83523, Egypt, Tel +20 1002973907, Fax +20 963216128, Email asmaa.elgafari@sci.svu.edu.eg

Purpose: The developed resistance of pathogenic microorganisms towards the currently used antimicrobial agents requires the fast search for newer potent antimicrobials. One of the most important ways to combat the previously mentioned disaster is the use of natural alternatives like medicinal plants. Our study aimed to estimate the anti-inflammatory property, and antibacterial effects of probiotics Lactiplantibacillus plantarum and ethanol extracts of Lawsonia inermis leaves against Staphylococcus aureus when they were used separately or collectively as synergism.

Material and Methods: Experimentally induced infected wound model in mice was created and divided into 10 groups then treated for two days by L. plantarum and L. inermis individually or in combination, followed by biochemical assays. The antibacterial, antiinflammatory, and wound healing activity were evaluated through histopathological sections taken before and after treatment.

Results: Our results revealed that L. plantarum and L. inermis mixture could inhibit growth of $S$. aureus and decrease the minimal inhibitory concentration (MIC) of L. plantarum to $2 \mathrm{mg} / \mathrm{mL}$. The mixture decreased level of both interleukin 6 (IL-6) and interferonalpha $(\mathrm{TNF}-\alpha)$ to a level near the normal uninfected group. Histopathological study showed that animals treated with both L. plantarum and $L$. inermis had achieved almost $90 \%$ healing.

Conclusion: These results suggest that L. plantarum and L. inermis mixture has synergistic effect on healing of infected wound. Keywords: Lactiplantibacillus plantarum, Lawsonia inermis, Staphylococcus aureus, wound healing

\section{Introduction}

The skin constitutes the largest organ that serves as the physical barrier protecting the human body against both toxic substances and foreign organisms. ${ }^{1}$ Staphylococcus aureus (S. aureus) is a common human pathogen causing many skin and soft tissue infections. It can result in different local and systemic infections like skin abscesses, sepsis, and toxic shock syndrome (TSS). Also, it can be more invasive and lead to life-threatening infections. ${ }^{2}$ Due to the evolution of bacteria and antibiotic resistance in recent decades, Methicillin resistant $S$. aureus (MRSA) infection rates increased worldwide, and clinical therapy for MRSA became more complicated. ${ }^{3}$ So, developing new drugs will provide more opportunities to treat S. aureus infections, offering more protection for human health. Hence, there is a huge need for natural alternatives targeting S. aureus with high efficacy and safety, especially they showed promising results even with pandemic diseases. $^{4-10}$

Probiotics are living microorganisms that confer a health benefit on the host. ${ }^{11,12}$ Lactiplantibacillus plantarum (L. plantarum) has been previously approved to produce antimicrobial peptides (bacteriocins). It has been demonstrated 
as a promising natural alternative against the resistant dermal and wound infections of $S$. aureus. Also, it was recommended to promote the innate immunity through stimulating the expression of $\beta$-defensin at wound sites. Moreover, it enhances the release of cytokines and chemokines during different stages of wound recovery which results in faster wound healing. ${ }^{13,14}$

Lawsonia inermis (L. inermis, Henna plant) has been used for centuries in herbal medicine. Its main chemical components are lawsone, mannite, mucilage, gallic acid, and tannic acid. The main ingredient is 2-dihydroxynaphthoquinone (lawsone). These substances have multiple free hydroxyls that can combine with carbohydrates and proteins in the bacterial cell wall causing antimicrobial activity. ${ }^{17}$ Lawsonia is one of the most studied plants for wound healing. ${ }^{18}$ As well as it's considered a cooling agent, astringent, antifungal, and antibacterial herb for the skin and hair, besides, it has a strong effect against $S$. aureus. ${ }^{19}$

The aim of our study is to investigate the effect of combining the probiotic "Lactiplantibacillus plantarum" with "Lawsonia inermis" to treat skin infection caused by S. aureus and to achieve better and, maybe, a quicker healing.

\section{Materials and Methods}

\section{Microorganisms' Inoculation Procedure}

Briefly, cultures of L. plantarum (ATCC 14917) were grown in MRS broth. MRS media (Acumedia, United States) was prepared by dissolving the solution in one liter of distilled water, mixing it carefully, and immersing it in the autoclave at $121^{\circ} \mathrm{C}$ for about 15 minutes. After that, the bacteria cultured by injecting $1 \mathrm{~mL}$ of $L$. plantarum into $50 \mathrm{~mL}$ MRS media and incubated at $37^{\circ} \mathrm{C}$ for about $24-48$ hours under a microaerophilic state and then were separately resuspended with sterile PBS to reach a concentration of $5 \times 10^{8} \mathrm{CFU} / \mathrm{mL}$, Bacteria were freshly prepared daily during the 8-week experiment. The bacterial concentration was determined using the McFarland standard, and test suspension was prepared using a new unadulterated culture to do the test on the organism and inoculating an appropriate broth.

\section{Culture of Staphylococcus aureus}

S. aureus strain USA300 (methicillin-resistant clone) was obtained from VACSERA then cultured, streaked on TSA agar, incubated for $24 \mathrm{~h}$ at $37^{\circ} \mathrm{C}$. Thereafter, the grown colonies of S. aureus grown on brain heart infusion broth $\left(24 \mathrm{~h}, 37^{\circ} \mathrm{C}\right)$ were centrifuged at $4000 \mathrm{~g}$ for $10 \mathrm{~min}$ at $4^{\circ} \mathrm{C}$.

\section{Lawsonia inermis Preparation}

L. inermis was purchased from a local fresh market and cleaned. The fresh leaves were collected, dried in shade, and then blended into powder. $200 \mathrm{mg}$ of the prepared powder was added to ethanol $(200 \mathrm{~mL})$ at RT for $20 \mathrm{~h}$. The produced mixture was filtered through a filter paper following a fine muslin cloth. Finally, the obtained filtrate was dried in an oven at $40{ }^{\circ} \mathrm{C}$ and the produced clear residue was used for the study. Also, preliminary phytochemical tests were performed on the extract. Voucher specimens were deposited at the herbarium of South Valley University, Egypt (unregistered herbarium) with $\mathrm{S} / \mathrm{N}$ number.

\section{In vitro Study}

Antibacterial activity of $L$. plantarum and $L$. inermis on $S$. aureus was measured after overnight liquid cultures quantitatively by measuring the MIC (Minimal Inhibitory Concentration) which is the minimum concentration required from the antimicrobial agent to inhibit the growth of microorganism. Microtitre plate (Nucleon, Germany) with two-fold dilutions of an antimicrobial agent is inoculated with a bacterial suspension with $\left(10^{5} \mathrm{CFU} / \mathrm{mL}\right)$ in $100 \mu \mathrm{L}$ MHB (Mueller-Hinton broth) and incubated at $37{ }^{\circ} \mathrm{C}$. Inoculated and uninoculated wells of antibacterial free broth were included to check for the adequacy of the broth to support the growth of the organism and check of sterility. The results represent data from three independent experiments. ${ }^{20}$ To quantify the interactions between L. inermis and L. plantarum, the fraction inhibitory index was measured as following: FIC of the agent $=\frac{\text { MIC of agent in combination }}{\text { MIC of agent alone }}$ 


\section{In vivo Study}

Six-week-old male white mice (Mus musculus), (bodyweight 25-30 gram) were used throughout the investigation. They were purchased from VACSERA, Egypt. The animals were kept at standardized conditions $\left(22-28^{\circ} \mathrm{C}, 60-70 \%\right.$ relative humidity, $12 \mathrm{~h}$ dark/light cycle). They were allowed access to food and water. The suspension of S. aureus was prepared that contains $1 \times 10^{8} \mathrm{CFU}$ that is used to induce infection at dose $0.1 \mathrm{~mL}$. The mice were anesthetized before and during the infliction of the experimental wounds. The surgical procedures were performed at sterile conditions using ketamine anesthesia $(120 \mathrm{mg} / \mathrm{kg})$. Transcutaneous wounds $(6 \mathrm{~mm}$ in diameter) were performed on the backs of the mice. Mice were sacrificed after five days; the injured skin specimens were aseptically removed, fixed with $10 \%$ formalin for $24 \mathrm{~h}$ at room temperature, and then embedded in paraffin according to standard histological methods.

-Mice were divided into 10 groups each group contains 6 mice:

1. Group 1 is uninfected (negative control).

2. Group 2 is infected by S. aureus (positive control).

3. Group 3 is uninfected and treated by L. plantarum (cells).

4. Group 4 is uninfected and treated by L. plantarum (supernatant).

5. Group 5 is uninfected and treated by L. inermis.

6. Group 6 is uninfected and treated by the combination between L. inermis, L. plantarum supernatant.

7. Group 7 is infected with $S$. aureus and treated by L. plantarum debris (cells) only.

8. Group 8 is infected with $S$. aureus and treated by L. plantarum supernatant only.

9. Group 9 is skin infected by S. aureus and treated by L. inermis.

10. Group 10 is skin infected by S. aureus and treated by the combination between L. plantarum supernatant with the L. inermis (1:1).

-Blood samples collection

Blood samples were taken from mice for white blood cell (WBC) count. The plasma was separated by centrifugation at $2000 \mathrm{rpm}$ for 15 minutes at $4{ }^{\circ} \mathrm{C}$, aliquot, and stored at $-80^{\circ} \mathrm{C}$ for ELISA assessment of IL- 6 and TNF- $\alpha$ (R\&D Systems). The results represent data from three independent experiments.

-Histopathological examination

Skin specimens were fixed in 10\% neutral buffered formalin solution, then each specimen was dehydrated in a graded alcohol series. Each specimen was assessed grossly for dissection and detection of skin infection. After treatment, the specimen was embedded in paraffin blocks. Five-micron thick sections were cut and stained with Hematoxylin and Eosin (H\&E) staining.

\section{Statistical Analysis}

Statistical Package for the Social Sciences (SPSS) version 22 was used to analyze the current data. Kolmogorov-Smirnov tests revealed that data was normally distributed, ie, variables were parametric. Post hoc Bonferroni correction test was utilized to show similarities in all the examined parameters among all groups. P value was considered significant if $<0.05$.

\section{Results}

\section{Minimal Inhibitory Concentration (MIC) of L. plantarum and L. inermis on S. aureus}

The MIC of L. plantarum and L. inermis on S. aureus was measured after tonight culture. As shown in Figure 1, the MIC of $L$. plantarum and L. inermis on $S$. aureus were $13 \mathrm{mg} / \mathrm{mL}$ and $0.0725 \mathrm{mg} / \mathrm{mL}$ respectively. Combined administration of L. plantarum and L. inermis could decrease the MIC of L. plantarum to $2 \mathrm{mg} / \mathrm{mL}$ but the MIC of L. inermis increased.

\section{ELISA Assessment of IL6 and TNF- $\alpha$ and WBCs Count}

The study enrolled (60) mice arranged into ten groups. Infected mice showed significant decreased level of Il-6 after treatment compared with the infected untreated group $(19.18 \pm 01 \mathrm{pg} / \mathrm{mL})$. We found that the most effective treatment was L. plantarum 


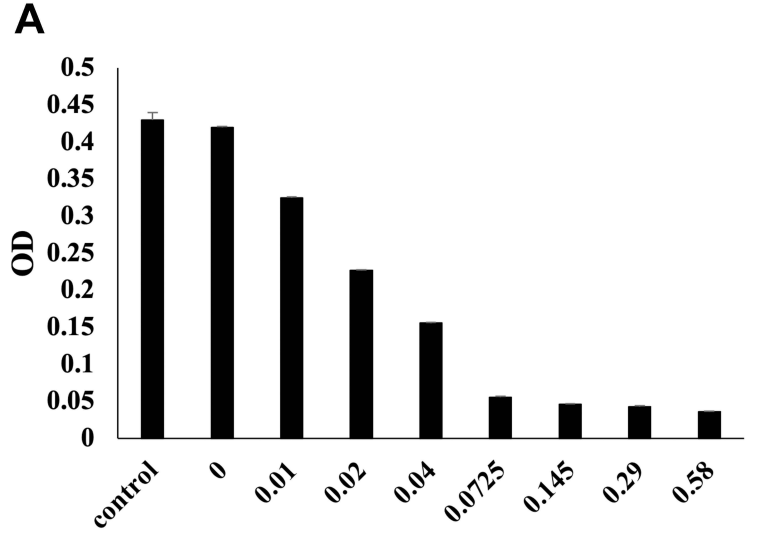

L. inermis conc. $\mathrm{mg} / \mathrm{mL}$
B

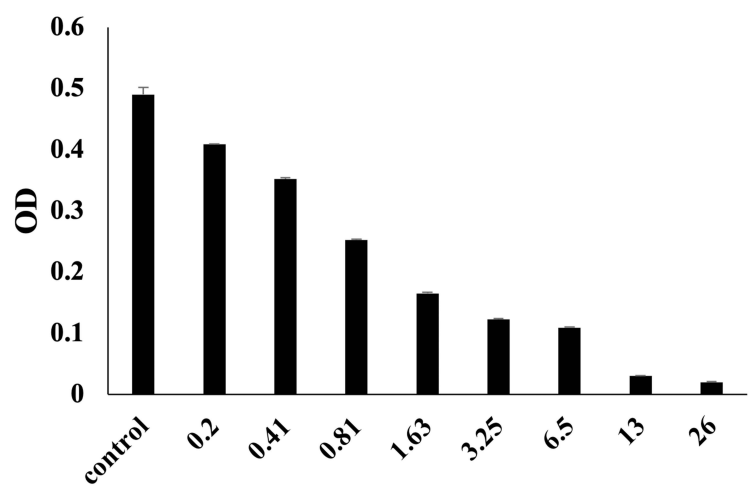

L. plantarum supernatant conc. $\mathrm{mg} / \mathrm{mL}$

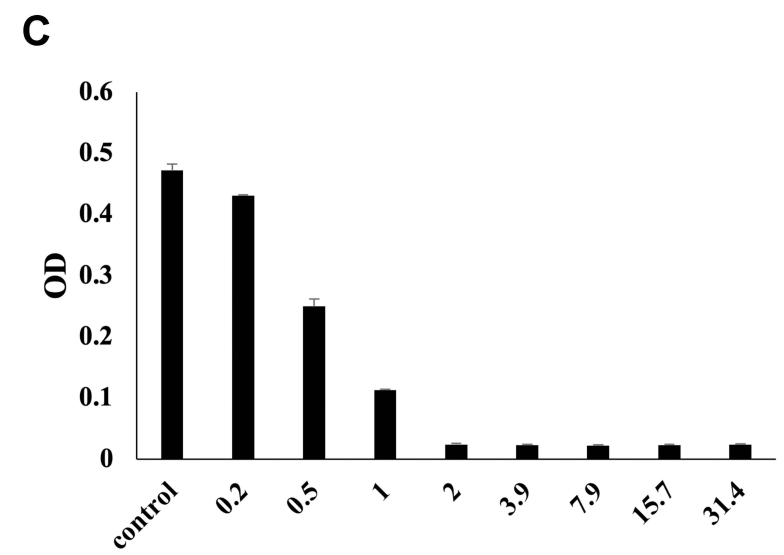

Combination conc. $\mathrm{mg} / \mathrm{mL}$

Figure I (A) Optical density (OD) of S. aureus with different conc. of $L$. inermis total extract (MIC $=0.0725 \mathrm{mg} / \mathrm{mL}$ ). (B) OD of $S$. aureus with different conc of $L$. plantarum supernatant (MIC=13mg/mL. (C) OD of $S$. aureus with different conc. of $L$. plantarum supernatant and $L$. inermis extract $(I: I)$, (MIC $=2 \mathrm{mg} / \mathrm{mL}$ ).

supernatant combined with $L$. inermis that showed a level near the normal uninfected group $(7.60 \pm 0.3 \mathrm{pg} / \mathrm{mL}, \mathrm{p}<0.05)$ (Table 1). TNF- $\alpha$ level was also significantly decreased in infected mice after treatment compared to the infected untreated group $(44.47 \pm 029 \mathrm{pg} / \mathrm{mL})$, and we found that the most effective treatment was $L$. inermis individually $(16.17 \pm 0.6 \mathrm{pg} / \mathrm{mL}, \mathrm{p}<$ $0.05)$ followed by the combination $(7400 \pm 58, \mathrm{p}<0.05)$ (Table 1). We assessed the total leucocytic count in infected mice before and after treatment, and we found that leukocytes count was the highest in infected mice $(10,183 \pm 44 / \mu \mathrm{L})$. The greatest decrease in leucocytic count is achieved by treatment with $L$. plantarum cell either individually $(7800 \pm 29 / \mu \mathrm{L}, \mathrm{p}<0.05)$ or in combination $(7400 \pm 58 / \mu \mathrm{L}, \mathrm{p}<0.05)$ (Table 1$)$.

\section{Histopathological Analysis of the Wound}

Microscopic examination of histopathological section of the uninfected wound before treatment revealed shallow ulcerative lesion scoring 4 (Figure 2A, and B,Table 2). ${ }^{21}$ Maximum wound healing was achieved by treatment with L. plantarum cell, L. inermis scoring 9 or the combination scoring 10 while Lactiplantibacillus supernatant group showed a characteristic wide ulcerative lesion. Tissue sections of uninfected wound after treatment showed secondary saprophytic infection with unknown capsulated multi-septated rod-shaped eosinophilic structures, both longitudinal and cross-sections were seen (Figure 2C-J). Microscopic examination of histopathological section of the infected wound before treatment revealed deep ulcerative lesion with complete exposure of epidermis that was extended to dermis scoring 3. Maximum wound healing was achieved by treatment with $L$ plantarum supernatant scoring 7 and the combination scoring 9. Tissue sections of infected wound after treatment with L. plantarum supernatant showed 
Table I IL-6, TNF- $\alpha$ Levels and WBCs Count of All Groups

\begin{tabular}{|c|c|c|c|c|c|c|c|c|c|c|}
\hline & \multicolumn{10}{|c|}{ Groups } \\
\hline & Uninfected & Infected & Lawsonia & $\begin{array}{l}\text { Lactiplantibacillus } \\
\text { Supernatant }\end{array}$ & $\begin{array}{c}\text { Lactiplantibacillus } \\
\text { Cell }\end{array}$ & Combination & $\begin{array}{l}\text { Lawsonia } \\
\text { Infected } \\
\text { with } \\
\text { S. aureus }\end{array}$ & $\begin{array}{l}\text { Lactiplantibacillus } \\
\text { Supernatant } \\
\text { Infected with } \\
\text { S. aureus }\end{array}$ & $\begin{array}{l}\text { Lactiplantibacillus } \\
\text { Cell Infected with } \\
\text { S. aureus }\end{array}$ & $\begin{array}{l}\text { Combination } \\
\text { Infected with } \\
\text { S. aureus }\end{array}$ \\
\hline $\begin{array}{l}\text { IL-6 } \\
\text { (pg/ } \\
\mathrm{mL})\end{array}$ & $3.33 \pm 0.88^{\mathrm{a}}$ & $\begin{array}{l}19.18 \\
\pm 012^{\mathrm{b}}\end{array}$ & $\begin{array}{c}4.65 \\
\pm 0.24^{\mathrm{a}}\end{array}$ & $4.7 I \pm 0.2 I^{\mathrm{a}, \mathrm{c}}$ & $4.73 \pm 0.18^{\mathrm{a}, \mathrm{c}}$ & $6.54 \pm 029^{\mathrm{c}, \mathrm{e}}$ & $9.01 \pm 029^{d, f}$ & $9.73 \pm 0.15^{d}$ & $10.21 \pm 0.15^{d}$ & $7.60 \pm 0.31^{e, f}$ \\
\hline $\begin{array}{l}\text { TNF- } \alpha \\
(\mathrm{pg} / \\
\mathrm{mL})\end{array}$ & $2.15 \pm 0.09^{\mathrm{a}}$ & $\begin{array}{l}44.47 \\
\pm 029^{\mathrm{b}}\end{array}$ & $\begin{array}{r}5.78 \\
\pm 0.15^{\mathrm{c}}\end{array}$ & $4.69 \pm 017^{\mathrm{a}, \mathrm{c}}$ & $10.41 \pm 0.3^{d}$ & $10.56 \pm 0.3^{d}$ & $16.17 \pm 0.6^{e}$ & $20.48 \pm 029^{f}$ & $32.67 \pm 1.45^{g}$ & $16.92 \pm 022^{\mathrm{e}}$ \\
\hline $\begin{array}{l}\text { WBCs/ } \\
\mu \mathrm{L}\end{array}$ & $7700 \pm 58^{\mathrm{a}, \mathrm{d}}$ & $\begin{array}{c}10,183 \\
\pm 44^{\mathrm{b}}\end{array}$ & $7190 \pm 21^{a}$ & $7700 \pm 58^{\mathrm{a}, \mathrm{d}}$ & $7583 \pm 44^{\mathrm{a}, \mathrm{d}}$ & $7100 \pm 58^{\mathrm{a}}$ & $9260 \pm 136^{b, c}$ & $8250 \pm 29^{c}$ & $7800 \pm 29^{d}$ & $7400 \pm 58^{\mathrm{a}, \mathrm{d}}$ \\
\hline
\end{tabular}

Notes: Data are shown as mean \pm standard error of the mean. Values in the similar line not having the same subscript are significantly different at $p<0.05$ in the two-sided test of equality for column means. Cells with no subscript are excluded from the test. Tests assume equal variances. Tests are adjusted for all pairwise comparisons within a row of each innermost sub table using the Bonferroni correction. 

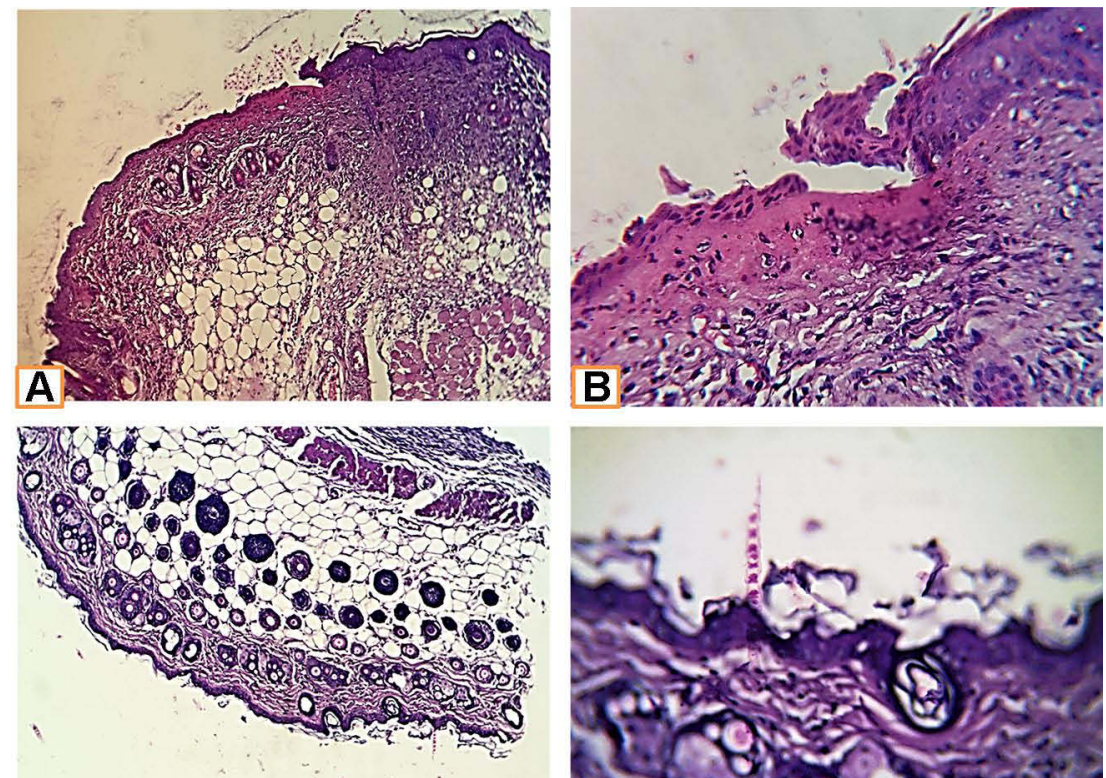

C
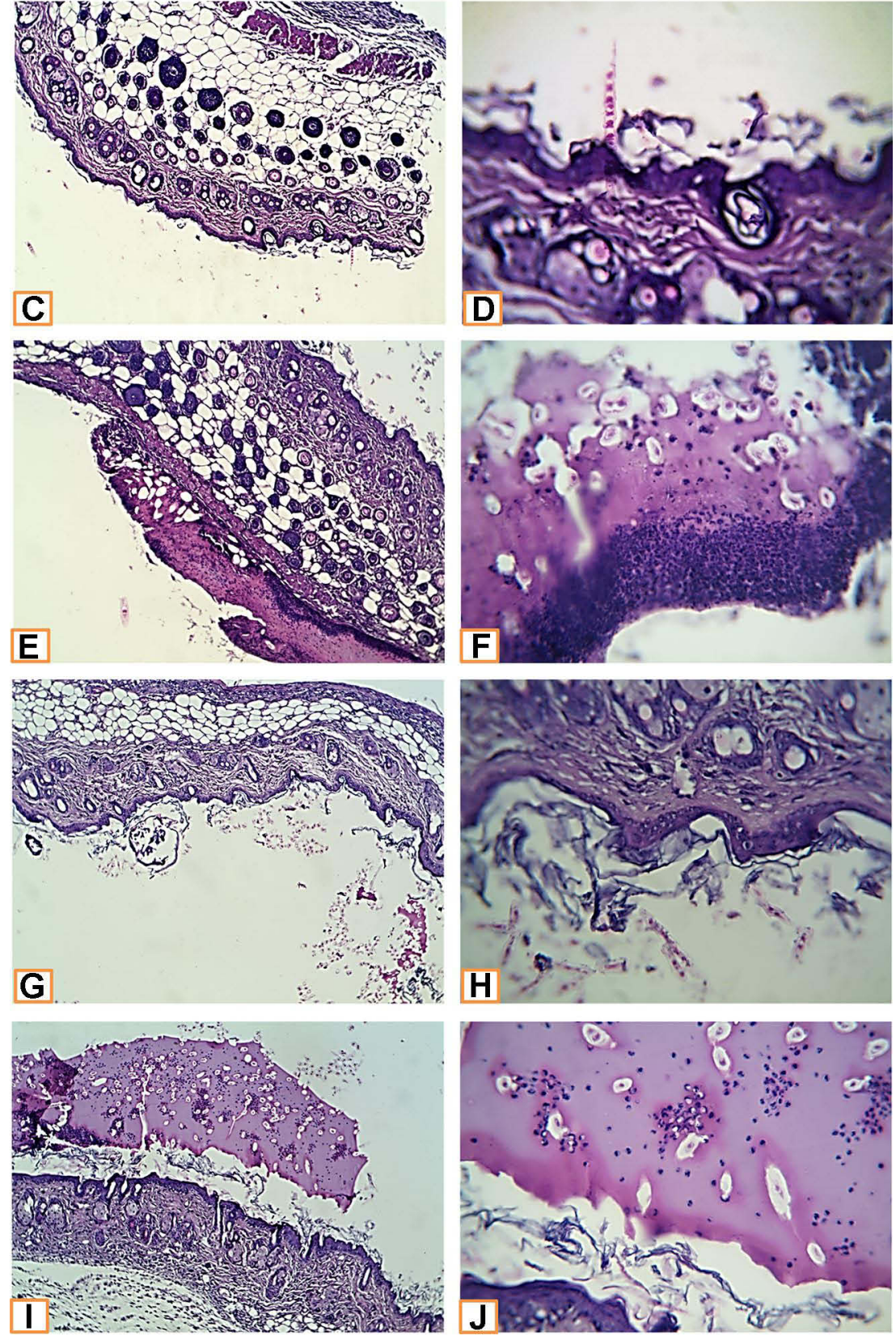

Figure 2 Histopathological examination of non infected wound before and after treatment with L. plantarum and or L. inermis. (A and B) Uninfected group. Sections showed a shallow ulcerative lesion with minimal epidermal and dermal florid inflammatory reaction. All other structures of the skin keep a normal morpho-histological appearance. (C and $\mathbf{D}$ ) Lactiplantibacillus cell group. The skin specimens revealed normal morpho-histological structures; however mild superficial contamination was seen, but without any significant pathologic reaction. (E and $\mathbf{F}$ ) that replaced large parts of the epidermis was seen. The ulcerated tissue is replaced by suppurative inflammatory exudate with a predominance of neutrophils and secondary saprophytic infection. ( $\mathbf{G}$ and $\mathbf{H}$ ) Lawsonia Group. Examined sections revealed a mild superficial exfoliative reaction with secondary contamination. (I and J) Combination group. Although clear ulcerative lesions were not seen, a peculiar exudative epidermal reaction was seen. Such exudate was seen covering the epidermis and contained a moderate number of neutrophils and the saprophytic contaminant. An epidermal exfoliative reaction was also seen (H\&E X400, zoomed section X30). 
Table 2 Parameters of Histologic Assessment of Wound

\begin{tabular}{|c|c|c|}
\hline Characteristic & Score & Features \\
\hline \multirow[t]{3}{*}{ Wound reepithelialization } & 0 & Migration of keratinocytes \\
\hline & 1 & Bridging of cells \\
\hline & 2 & Keratinization \\
\hline \multirow[t]{3}{*}{ Inflammatory cells } & 0 & Absence \\
\hline & 1 & Mild presence \\
\hline & 2 & Marked presence \\
\hline \multirow[t]{3}{*}{ Fibroblasts } & 0 & Absence \\
\hline & 1 & Mild presence \\
\hline & 2 & Marked presence \\
\hline \multirow[t]{3}{*}{ New vessels } & 0 & Absence \\
\hline & 1 & Mild presence \\
\hline & 2 & Marked presence \\
\hline \multirow[t]{3}{*}{ Collagen } & 0 & Absence \\
\hline & 1 & Mild presence \\
\hline & 2 & Marked presence \\
\hline
\end{tabular}

secondary saprophytic infection with unknown capsulated multi-septated rod-shaped eosinophilic structures (Figure 3A-J).

\section{Discussion}

L. inermis (Henna) has been commonly used over centuries for treatment of wound due to its healing properties. Muhammed et al had described usage of henna in management of burn wound infections due to its antimicrobial and antiinflammatory properties. ${ }^{22}$ L. plantarum is a probiotic, which is known as a natural alternative for the treatment of the resistant dermal and wound infections of $S$. aureus. ${ }^{14}$ The fixed combination of probiotics and herbal extracts has been investigated in many inflammatory diseases. ${ }^{15}$ This combination was used effectively in treatment of irritable bowel syndrome, inflammatory bowel disease and skin diseases. ${ }^{15,16}$ This study discussed the potential synergistic effect of combining L. inermis and L. plantarum for treatment of infected wound.

Our microbiological studies revealed that both L. inermis and L. plantarum could inhibit $S$. aureus growth. This comes in agreement with previous studies that described antibacterial properties of L. inermis and L. plantarum. ${ }^{14,23,24}$ The MIC of L. plantarum could be decreased from $13 \mathrm{mg} / \mathrm{mL}$ to $2 \mathrm{mg} / \mathrm{mL}$ when combined with L. inermis indicating a synergistic effect in case of L. plantarum with FIC (fraction inhibitory concentration) $=0.5$. On the other side the combination had an antagonistic effect on L. inermis with MIC increased from 0.7 to $13 \mathrm{mg} / \mathrm{mL}$ with FIC (fraction inhibitory concentration) $=9 .^{25}$ IL-6 is a proinflammatory cytokine paradoxically associated with both skin healing and inflammation, in our experiment IL-6 level was decreased in infected mice after treatment in comparison with the infected untreated group, and we found the most effective sample is L. plantarum in combination with L. inermis that showed level near from normal uninfected group. ${ }^{26}$ Tumor necrosis factor (TNF) is also a proinflammatory cytokine implicated in the pathophysiology of various inflammatory diseases. ${ }^{27}$ TNF- $\alpha$ was decreased in our experiment in infected mice after treatment in comparison with the infected untreated group.In contrast, Galehdari et al reported 

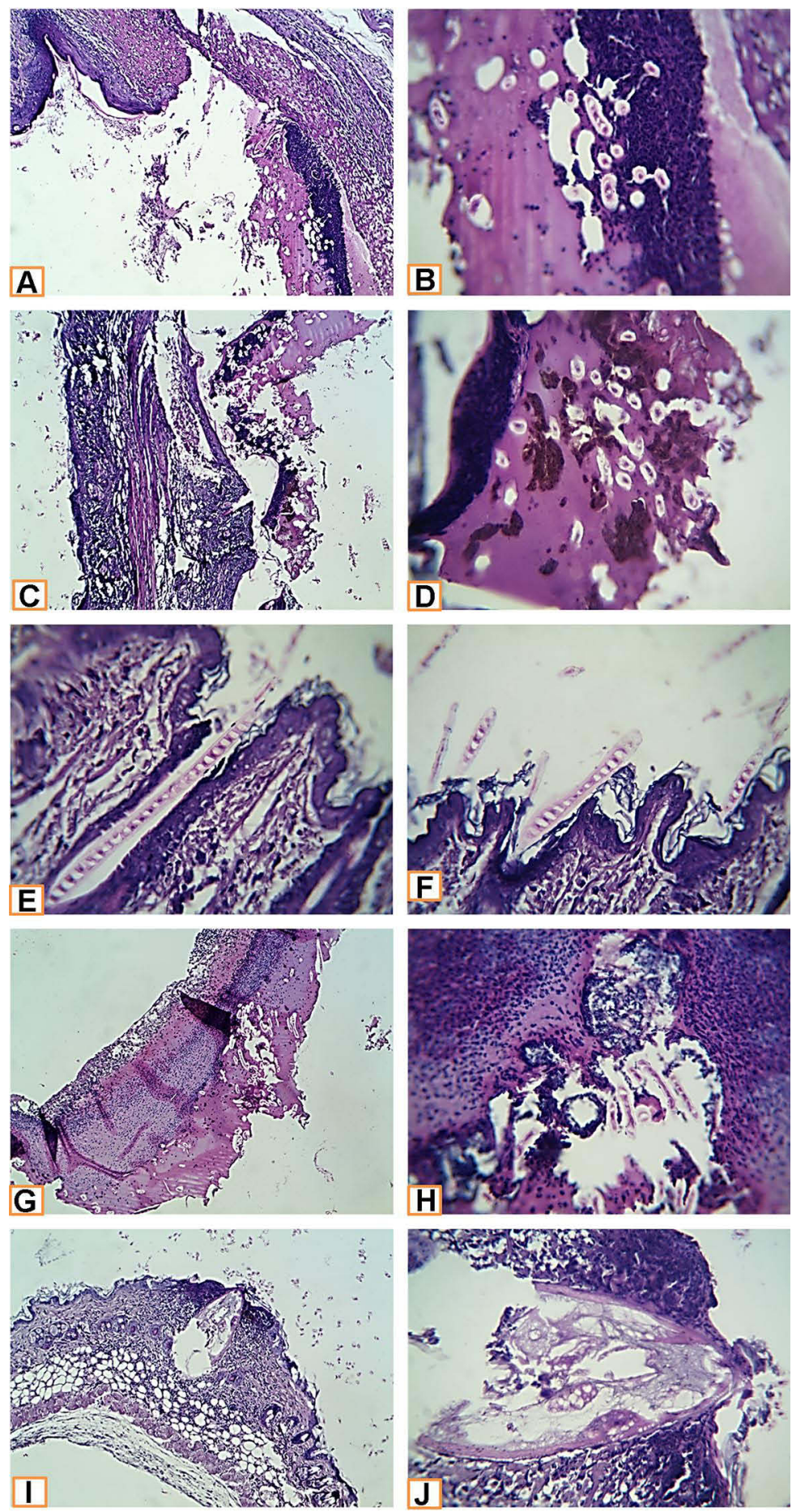

Figure 3 Histopathological examination of infected wound before and after treatment with $L$. plantarum and or $L$ inermis. (A and B) Infected group. Sections showed deep ulcerative lesions with complete exposure of the epidermis and extending to the dermis. An extensive inflammatory reaction with secondary infection and predominance of neutrophilic infiltration were seen. ( $(\mathbf{C}$ and $\mathbf{D})$ Lactiplantibacillus cell group infected with S. aureus. A wide detached ulcer was seen overlying denuded dermal tissue. The ulcerated materials were mostly formed from suppurative exudate rich in neutrophils and contained contaminated saprophytes and amorphous brownish materials (bloody-like). (E and F) Lactiplantibacillus supernatant group infected with S. aureus. The skin structures were completely normal. An elongated septated eosinophilic contaminant of unknown nature was seen overlying the epidermis and superficially invaded it. ( $\mathbf{G}$ and $\mathbf{H}$ ) Lawsonia group infected with S. aureus. A huge detached ulcerative tissue was seen. It was formed from suppurative exudate rich in neutrophils, bacterial colonies, dead necrotic tissue, and saprophytic structures. (I and J) Combination group infected with S. aureus. A characteristic narrow, deep ulcerative lesion was seen. It extended deep to the hypodermis. The contents of the ulcer were funneled shape hyalinized membranous structures entangling necrotic debris. Neutrophils extensively infiltrated the adjacent skin tissue; other parts of the skin in the vicinity of the ulcer showed a florid inflammatory reaction, enclosing different types of leucocytes (H\&E X400, zoomed section X30). 
increase in level of TNF- $\alpha$ in mice treated with herbal mixture containing L. inermis. These contradictory results could be due to the effect of other herbs used in the study or due to pathophysiology of diabetes as the study was conducted on diabetic rats. ${ }^{28}$ Consistent with our results, Rakhshandeh et al reported potential neuroprotective effects of $L$. inermis due to its anti-oxidant, and anti-inflammatory effects manifested by decreased level of TNF- $\alpha .{ }^{29}$

In the histopathological study, the healing capacity in uninfected mice is $90 \%$ in the L. inermis group and combination group. But, in infected mice only L. plantarum group and combination group could achieve almost $90 \%$ healing. This indicated that L. inermis mainly helped in skin regeneration while Lactiplantibacillus mainly helped in elimination of infection. In line with this conclusion, many studies reported $L$. inermis extracts were capable of promoting wound healing activity through enhanced wound contraction and tensile strength. ${ }^{30,31}$

\section{Conclusion}

L. plantarum and L. inermis combination has synergistic effect on healing of infected wound. The combination could effectively decrease the level of both IL- 6 and TNF- $\alpha$. Thus, these findings indicate that coadministration of L. plantarum and $L$. inermis can be used as treatment in resistant wound infection.

\section{Institutional Review Board Statement}

All experiments were approved by ethics committee of the care and use of animals in education and scientific research at Sadat City University (Approval No. 12-214 at 21/6/2020). The use and care of experimental animals, used in this study, comply with the Egyptian animal welfare laws and policies.

\section{Data Sharing Statement}

The authors confirm that the data supporting the findings of this study are available within the article.

\section{Acknowledgments}

The authors would like to thank the Deanship of Scientific Research at Taif University for funding this work through Taif University Researchers Supporting Project number (TURSP-2020/220), Taif Uni-versity, Taif, Saudi Arabia.

\section{Author Contributions}

All authors contributed to data analysis, drafting or revising the article, gave final approval of the version to be published, agreed to the submitted journal, and agree to be accountable for all aspects of the work.

\section{Disclosure}

The authors report no conflicts of interest in this work.

\section{References}

1. Baroni A, Buommino E, De Gregorio V, Ruocco E, Ruocco V, Wolf R. Structure and function of the epidermis related to barrier properties. Clin Dermatol. 2012;30(3):257-262. doi:10.1016/j.clindermatol.2011.08.007

2. Krishna S, Miller LS. In innate and adaptive immune responses against Staphylococcus aureus skin infections. Semin Immunopathol. 2012;34 (2):261-280. doi:10.1007/s00281-011-0292-6

3. Guo Y, Song G, Sun M, Wang J, Wang Y. Prevalence and therapies of antibiotic-resistance in Staphylococcus aureus. Front Cell Infect Microbiol. 2020;10:107. doi:10.3389/fcimb.2020.00107

4. Zaki AA, Al-Karmalawy AA, El-Amier YA, Ashour AJN. Molecular docking reveals the potential of Cleome amblyocarpa isolated compounds to inhibit COVID-19 virus main protease. New J Chem. 2020;44(39):16752-16758. doi:10.1039/D0NJ03611K

5. Soltane R, Chrouda A, Mostafa A, et al. Strong inhibitory activity and action modes of synthetic maslinic acid derivative on highly pathogenic coronaviruses: COVID-19 drug candidate. Pathogens. 2021;10(5):623. doi:10.3390/pathogens10050623

6. Zaki AA, Ashour A, Elhady SS, Darwish KM, Al-Karmalawy AA. Calendulaglycoside A showing potential activity against SARS-CoV-2 main protease: molecular docking, molecular dynamics, and SAR studies. J Tradit Complement Med. 2021. doi:10.1016/j.jtcme.2021.05.001

7. Kandeil A, Mostafa A, Kutkat $\mathrm{O}$, et al. Bioactive polyphenolic compounds showing strong antiviral activities against severe acute respiratory syndrome coronavirus 2. Pathogens. 2021;10(6):758. doi:10.3390/pathogens10060758

8. Ghanem A, Emara HA, Muawiya S, Abd El Maksoud AI, Al-Karmalawy AA, Elshal MF. Tanshinone IIA synergistically enhances the antitumor activity of doxorubicin by interfering with the PI3K/AKT/mTOR pathway and inhibition of topoisomerase II: in vitro and molecular docking studies. New J Chem. 2020;44(40):17374-17381. doi:10.1039/D0NJ04088F 
9. Elmaaty AA, Darwish KM, Khattab M, et al. In a search for potential drug candidates for combating COVID-19: computational study revealed salvianolic acid B as a potential therapeutic targeting 3CLpro and spike proteins. J Biomol Struct Dyn. 2021:1-28. doi:10.1080/ 07391102.2021 .1918256

10. Al-Karmalawy AA, Elshal MF. Concanavalin-A shows synergistic cytotoxicity with tamoxifen via inducing apoptosis in estrogen receptor-positive breast cancer: in vitro and molecular docking studies. Pharm Sci. 2021. doi:10.34172/PS.2021.22

11. Ostad S, Salarian A, Ghahramani M, Fazeli M, Samadi N, Jamalifar H. Live and heat-inactivated lactobacilli from feces inhibit Salmonella typhi and Escherichia coli adherence to Caco-2 cells. Folia Microbiol. 2009;54(2):157-160. doi:10.1007/s12223-009-0024-7

12. Soltan MA, Elbassiouny N, Gamal H, et al. In silico prediction of a multitope vaccine against Moraxella catarrhalis: reverse vaccinology and immunoinformatics. Vaccines. 2021;9(6):669. doi:10.3390/vaccines 9060669

13. Ong JS, Taylor TD, Yong CC, et al. Lactobacillus plantarum USM8613 aids in wound healing and suppresses Staphylococcus aureus infection at wound sites. Probiotics Antimicrob Proteins. 2019;11(1):1-13. doi:10.1007/s12602-017-9329-z

14. Onbas T, Osmanagaoglu O, Kiran F. Potential properties of Lactobacillus plantarum F-10 as a bio-control strategy for wound infections. Probiotics Antimicrob Proteins. 2019;11(4):1110-1123. doi:10.1007/s12602-018-9486-8

15. Cocetta V, Catanzaro D, Borgonetti V, et al. A fixed combination of probiotics and herbal extracts attenuates intestinal barrier dysfunction from inflammatory stress in an in vitro model using Caco-2 cells. Recent Pat Food Nutr Agric. 2019;10(1):62-69. doi:10.2174/ 2212798410666180808121328

16. Kim J, Kim H, Jeon S, Jo J, Kim Y, Kim H. Synergistic antibacterial effects of probiotic lactic acid bacteria with Curcuma longa rhizome extract as synbiotic against Cutibacterium acnes. Appl Sci. 2020;10(24):8955. doi:10.3390/app10248955

17. Puri B, Hall A. Phytochemical Dictionary: A Handbook of Bioactive Compounds from Plants. CRC press; 1998.

18. Nigussie D, Makonnen E, Tufa TB, et al. Systematic review of Ethiopian medicinal plants used for their anti-inflammatory and wound healing activities. J Ethnopharmacol. 2021;276:114179. doi:10.1016/j.jep.2021.114179

19. Al-Rubiay KK, Jaber NN, Al-Mhaawe B, Alrubaiy LK. Antimicrobial efficacy of henna extracts. Oman Med J. 2008;23(4):253.

20. Wiegand I, Hilpert K, Hancock RE. Agar and broth dilution methods to determine the minimal inhibitory concentration (MIC) of antimicrobial substances. Nat Protoc. 2008;3(2):163-175. doi:10.1038/nprot.2007.521

21. Gupta A, Kumar P. Assessment of the histological state of the healing wound. Plast Aesthetic Res. 2015;2(5):239-242. doi:10.4103/23479264.158862

22. Muhammad H, Muhammad S. The use of Lawsonia inermis Linn. (henna) in the management of burn wound infections. Afr J Biotechnol. 2005;4:934-937.

23. Usman R, Rabiu U. Antimicrobial activity of Lawsonia inermis (henna) extracts. Bayero J Pure Appl Sci. 2018;11(1):167-171. doi:10.4314/ bajopas.v11i1.27S

24. Rekik DM, Khedir SB, Daoud A, Moalla KK, Rebai T, Sahnoun Z. Wound healing effect of Lawsonia inermis. Skin Pharmacol Physiol. 2019;32 (6):295-306. doi:10.1159/000501730

25. Balouiri M, Sadiki M, Ibnsouda SK. Methods for in vitro evaluating antimicrobial activity: a review. J Pharm Anal. 2016;6(2):71-79. doi:10.1016/ j.jpha.2015.11.005

26. Lee EG, Mickle-Kawar BM, Gallucci RMIL-6. deficiency exacerbates skin inflammation in a murine model of irritant dermatitis. $J$ Immunotoxicol. 2013;10(2):192-200. doi:10.3109/1547691X.2012.707700

27. Hernández MV, Meineri M, Sanmartí R. Skin lesions and treatment with tumor necrosis factor alpha antagonists. Reumatol Clin. 2013 ;9(1):53-61. doi:10.1016/j.reumae.2012.07.008

28. Galehdari H, Negahdari S, Kesmati M, Rezaie A, Shariati G. Effect of the herbal mixture composed of Aloe Vera, Henna, Adiantum capillus-veneris, and Myrrha on wound healing in streptozotocin-induced diabetic rats. BMC Complement Altern Med. 2016;16(1):386. doi:10.1186/s12906-016-1359-7

29. Rakhshandeh H, Ghorbanzadeh A, Negah SS, Akaberi M, Rashidi R, Forouzanfar F. Pain-relieving effects of Lawsonia inermis on neuropathic pain induced by chronic constriction injury. Metab Brain Dis. 2021;36(7):1709-1716.

30. Nayak BS, Isitor G, Davis EM, Pillai GK. The evidence based wound healing activity of Lawsonia inermis Linn. Phytother Res. 2007;21 (9):827-831. doi:10.1002/ptr.2181

31. Daemi A, Farahpour MR, Oryan A, Karimzadeh S, Tajer E. Topical administration of hydroethanolic extract of Lawsonia inermis (henna) accelerates excisional wound healing process by reducing tissue inflammation and amplifying glucose uptake. Kaohsiung J Med Sci. 2019;35 (1):24-32. doi:10.1002/kjm2.12005

Infection and Drug Resistance

Dovepress

\section{Publish your work in this journal}

Infection and Drug Resistance is an international, peer-reviewed open-access journal that focuses on the optimal treatment of infection (bacterial, fungal and viral) and the development and institution of preventive strategies to minimize the development and spread of resistance. The journal is specifically concerned with the epidemiology of antibiotic resistance and the mechanisms of resistance development and diffusion in both hospitals and the community. The manuscript management system is completely online and includes a very quick and fair peer-review system, which is all easy to use. Visit http://www.dovepress.com/testimonials.php to read real quotes from published authors.

Submit your manuscript here: https://www.dovepress.com/infection-and-drug-resistance-journal 